\title{
Etika Alquran Menuju Masyarakat Adil Dan Makmur
}

\author{
Muhammad Chirzin \\ Universitas Islam Negeri (UIN) Sunan Kalijaga Yogyakarta \\ muchirzin@gmail.com
}

DOI: http://dx.doi.org/10.29240/alquds.v1i2.244

Submitted: 2017-10-13 | Revised: 2017-11-23| Accepted: 2017-12-01

\begin{abstract}
Qur'anic Ethics Toward a Fair and Prosperous Society. A fair, prosperous and happy life are the inner desire of every human being. In order to realize these ideals, human beings necessarily recognize each other's potential, advantages and/or disadvantages to complement each other; mutual learning, mutual giving and receiving. The presence of the prophets brought the Shari'ah of Allah SWT with the aim of establishing a just humanitarian system. The just society is reflected in the right and proper group life.In the context of human relationships, justice in the Quran contains three meanings. First, fair in the same sense. Second, fair in a balanced sense. Third, fair in the sense of attention to the rights of individuals and give those rights to each owner and get a social justice. A prosperous society is a prosperous, capable, and rich society.In the context of the state, prosperity is a state of affluence that encompasses the lives of all people.Islamic justice is superior to any formal justice of any human law. It penetrates deep down to the deepest feelings. One of the prerequisites to realize the harmony of human life is peace. When there is a dispute, it is necessarily settled in the most fair manner. For that every member of the community must be willing to sacrifice for the common good and strive for the common goal. Society will undoubtedly help each other to realize a just and prosperous life all of time.
\end{abstract}

Keywords: Alquran, ethics, fair, prosperous, peaceful.

\begin{abstract}
Abstrak: Kehidupan yang adil, makmur, sejahtera dan bahagia lahir batin adalah dambaan setiap insan. Demi mewujudkan cita-cita tersebut manusia niscaya saling mengenali potensi, kelebihan dan/atau kekurangan masing-masing untuk saling melengkapi; saling belajar, saling memberi dan menerima. Kehadiran para rasul membawa syariat Allah SWT dengan tujuan untuk menegakkan sistem kemanusiaan yang adil. Masyarakat adil tercermin dalam kehidupan kelompok yang benar dan selayaknya. Dalam konteks hubungan antarmanusia, keadilan dalam Alquran mengandung tiga makna. Pertama, adil dalam arti sama. Kedua, adil dalam arti seimbang. Ketiga, adil dalam arti perhatian terhadap hak-hak individu dan memberikan hak-hak itu kepada setiap pemiliknya yang melahirkan keadilan sosial. Masyarakat yang makmur ialah masyarakat yang sejahtera, mampu, dan kaya. Dalam konteks negara, kemakmuran ialah keadaan berkecukupan yang meliputi kehidupan seluruh rakyatnya. Keadilan Islam
\end{abstract}


lebih tinggi daripada keadilan formal hukum mana pun yang dibuat manusia. Ia menembus sampai ke lubuk perasaan yang paling dalam. Salah satu prasyarat mewujudkan keharmonisan hidup manusia ialah kedamaian. Bilamana ada perselisihan niscaya diselesaikan dengan cara yang seadil-adilnya. Untuk itu setiap anggota masyarakat harus rela berkorban demi kemaslahatan bersama dan berjuang demi citacita bersama. Masyarakat niscaya bahu-membahu mewujudkan kehidupan yang adil dan makmur sepanjang masa.

Kata kunci: Alquran, etika, adil, makmur, damai.

\section{Pendahuluan}

Teori etika adalah gambaran rasional mengenai hakikat dan dasar perbuatan dan keputusan yang benar serta prinsip-prinsip yang menentukan klaim bahwa perbuatan dan keputusan tersebut secara moral diperintahkan dan dilarang. ${ }^{1}$ Etika berhubungan erat dengan konsep tentang baik dan buruk serta motif seseorang mengambil keputusan untuk melakukan atau tidak melakukan sesuatu yang baik maupun yang buruk. Rasulullah SAW bersabda, "Sesunggubnya perbuatan itu tergantung pada niat dan setiap orang akan memperoleh apa yang ia inginkan sesuai dengan niatnya." (HR Bukhari dan Muslim).

Etika atau akhlak adalah jantung ajaran Islam. Alquran menegaskan bahwa Nabi Muhammad saw berakhlak agung (QS Al-Qalam/68:4). Begitu sentralnya etika dalam Islam sehingga Nabi Muhammad SAW pun bersabda, "Sesungguhnya aku diutus untuk menyempurnakan kemuliaan akhlak." Ketika salah seorang sahabat bertanya tentang akhlak Rasulullah SAW, "Aisyah menjawab, "Akhak Rasulullah SAW adalah Alquran."

Maqashid asy-syariah merupakan landasan etis dalam Alquran untuk mewujudkan masyarakat adil dan makmur. Manusia tidak mungkin bisa merealisasikan tujuan dan sasarannya melainkan apabila semua unsur perkembangan terpenuhi dengan menggunakan dan mengambil hak-haknya secara sempurna. Hak-hak utama yang dijamin oleh Islam adalah hak hidup, hak memiliki, hak mendapatkan perlindungan kehormatan, hak kemerdekaan, hak persamaan, dan hak untuk belajar. ${ }^{2}$

Masyarakat adalah kumpulan individu yang menjalin kehidupan bersama sebagai satu kesatuan dan saling membutuhkan. ${ }^{3}$ Bangsa Indonesia terdiri dari berbeda-beda suku, adat istiadat, bahasa, warna kulit dan agama. Sebagian terdiri dari masyarakat kota yang bergerak dalam bidang industri, perdagangan, dan

1 Majid Fakhry, Etika Islam, terjemah Zakiyuddin Baidhawy (Yogyakarta: Pustaka Pelajar, 1996), xv.

2 Ahmad al-Mursi Husain Jauhar, Maqashid Syari'ah, terjemah Khikmawati Jakarta: Amzah, 2010), vii.

3J. S. Badudu dan Sutan Mohammad Zain, Kamus Umum Babasa Indonesia (Jakarta: Pustaka Sinar Harapan, 1996), 872. 
lain-lain, dan sebagian besar lainnya terdiri dari masyarakat desa yang terutama bergerak dalam bidang pertanian. Kadang timbul ketegangan dan kesalahpahaman antara satu kelompok dengan kelompok yang lain karena perbedaan kepentingan, pandangan, pedoman dan filsafat hidup serta wawasan terhadap kehidupan dunia dan alam semesta.

Allah SWT berfirman: "Hai manusia, sesunggubnya Kami menciptakan kamu dari satu pasang laki-laki dan perempuan, dan Kami jadikan kamu beberapa bangsa dan suku bangsa supaya kamu saling mengenal (bukan supaya saling membenci). Sungguh, orang yang paling mulia diantara kamu dalam pandangan Allab ialah yang paling bertakwa. Allah Maha Mengetabui lagi Maba Mengenal”. (Al-Hujurat/49:13)

Dalam ayat yang lain Allah SWT berfirman: "Dan di antara tanda-tanda kebesaran-Nya Ia menciptakan langit dan bumi, dan aneka macam perbedaan bahasa dan warna kulit. Sungguh, yang demikan ialah tanda-tanda bagi orang-orang yang berpengetabuan”. (Ar-Rum/30:22)

Perbedaan dalam bahasa dan warna kulit dapat dilihat dari segi geografi atau waktu tertentu dalam sejarah. Semua umat manusia diciptakan dari sepasang orangtua, ibu dan bapak, Adam dan Hawa. ${ }^{4}$ Dengan perbedaanperbedaan tersebut manusia niscaya saling mengenali potensi, kelebihan dan/atau kekurangan masing-masing untuk saling belajar, saling memberi dan menerima, demi mewujudkan kehidupan bersama yang sejahtera; adil, makmur dan bahagia lahir dan batin.

Islam datang untuk semua lapisan masyarakat di dunia, sejak masyarakat primitif, termasuk suku terasing, yang masih terbelakang dalam segala bidang, hingga masyarakat modern yang berperadaban tinggi dan maju dari segi ekonomi, pendidikan dan sebagainya. Islam datang untuk membimbing kehidupan manusia dalam segala seginya. Kehadiran para rasul membawa syariat Allah SWT yang satu dengan tujuan untuk menegakkan sistem kemanusiaan yang adil..$^{5}$

Allah SWT memberikan tiga karunia kepada manusia, yakni kitab, neraca dan besi yang merupakan lambang tiga perkara yang mengikat masyarakat sekaligus, yaitu wahyu yang menganjurkan perbuatan baik dan mencegah yang munkar; keadilan yang dapat memberikan haknya kepada setiap orang; dan kekuasaan hukum yang kuat, yang dengan tegas sanksi dapat dilaksanakan kepada setiap pelanggarnya. ${ }^{6}$

Pasal 33 Undang-Undang Dasar Negara Republik Indinesia 1945 berbunyi: (1) Perekonomian disusun sebagai usaha bersama berdasar atas asas kekeluargaan; (2) Cabang-cabang produksi yang penting bagi negara dan yang

\footnotetext{
${ }^{4}$ Abdullah Yusuf Ali, Quran Terjemahan dan Tafsirnya, 1032, footnote 3527.

${ }^{5}$ M. Quraish Shihab, Wawasan Al-Quran (Bandung: Mizan, 2007), 112.

${ }^{6}$ Abdullah Yusuf Ali, Quran Terjemahan, 1409 footnote 5313.
} 
menguasai hajat hidup orang banyak dikuasai oleh negara; (3) Bumi, air dan kekayaan alam yang terkandung di dalamnya dikuasai oleh Negara dan dipergunakan untuk sebesar-besar kemakmuran rakyat. ${ }^{7}$

Allah SWT menetapkan kepemimpinan sebagai perjanjian Ilahi yang melahirkan tanggung jawab menentang kezaliman dan menegakkan keadilan. ${ }^{8}$ Keadilan adalah syarat bagi terciptanya kesempurnaan pribadi, standar kesejahteraan masyarakat, dan sekaligus jalan terdekat menuju kebahagiaan ukhrawi. ${ }^{9}$ Pemimpin harus adil dan jujur dalam menyelenggarakan kepemimpinan dalam segala lini kehidupan. Pemimpin niscaya mengabdi pada rakyat, dan bukan rakyat mengabdi pada pemimpin.

Tulisan ini menelisik norma-norma Alquran tentang keadilan dan kemakmuran serta bagaimana langkah-langkah yang harus ditempuh untuk merealisikan idealitas tersebut dalam kehidupan nyata. Kajian ini menggunakan metode tematik untuk menemukan jawaban atas pertanyaan-pertanyaan mendasar tentang keadilan dan kemakmuran menurut Alquran.

\section{Pengertian Adil dan Makmur}

Allah SWT menetapkan syariat Islam untuk mewujudkan kehidupan yang adil dan makmur dalam segala aspeknya. Dalam Kamus Umum Bahasa Indonesia kata adil artinya tidak berat sebelah, jujur, tidak berpihak, sama rata. Keadilan ialah kejujuran, kelurusan, keikhlasan yang tidak berat sebelah. ${ }^{10}$ Masyarakat adil tercermin dalam kehidupan kelompok yang benar dan selayaknya. ${ }^{11}$ Kata adil berasal dari kosakata bahasa Arab dari akar kata 'adala-ya'dilu-'adl, yang mengandung arti berbuat adil; keadilan; kejujuran; sama, rata; sepadan; tengah-

7Penjelasan Pasal 33 ayat (3) UUD Negara Republik Indonesia 1945 tersebut di atas adalah sebagai berikut."Dalam pasal 33 tercantum dasar demokrasi ekonomi.Produksi dikerjakan oleh semua, untuk semua di bawah pimpinan atau penilikan anggota-anggota masyarakat.Kemakmuran masyarakatlah yang diutamakan, bukan kemakmuran orangseorang.Sebab itu perekonomian disusun sebagai usaha bersama berdasar atas azas kekeluargaan. Bangun perusahaan yang sesuai dengan itu ialah koperasi. Perekonomian berdasar atas demokrasi ekonomi, kemakmuran bagi semua orang! Sebab itu cabang-cabang produksi yang penting bagi Negara dan yang menguasai hidup orang banyak harus dikuasai oleh Negara.Kalau tidak, tampuk produksi jatuh ke tangan orang-seorang yang berkuasa dan rakyat banyak ditindasinya.Hanya perusahaan yang tidak menguasai hajat hidup orang banyak yang boleh ada di tangan orang-seorang. Bumi dan air dan kekayaan alam yang terkandung dalam bumi adalah pokok-pokok kemakmuran rakyat.Sebab itu harus dikuasai oleh Negara dan dipergunakan untuk sebesar-besar kemakmuran rakyat." Maria S.W. Sumardjono, "Memaknai Kembali Hak Menguasai Negara atas Sumberdaya Alam Pasca Putusan Mahkamah Konstitusi dan Tindaklanjutnya", Kuliah Inangurasi Akademi Ilmu Pengetahuan Indonesia di Universitas Gadjahmada Yogyakarta, 3 September 2013, 3-4.

${ }^{8} \mathrm{M}$. Quraish Shihab, Wawasan Al-Quran, 112.

${ }^{9}$ M. Quraish Shihab, Wawasan Al-Quran, 113.

${ }^{10} \mathrm{~J}$. S. Badudu dan Sutan Mohammad Zain, Kamus Umum Bahasa Indonesia Jakarta: Pustaka Sinar Harapan, 1996), 8.

${ }^{11}$ Eko Endarmoko, Tesaurus Bahasa Indonesia (Jakarta: Gramedia, 2009), 6. 
tengah; ${ }^{12}$ lurus; menetapkan hukum dengan benar; ${ }^{13}$ bertindak sama dalam memberikan balasan; jika baik maka balasannya baik, dan jika buruk maka balasannya buruk. ${ }^{14}$

Kata adil dan derivasinya terulang 28 kali dalam Alquran. Hal itu sekilas menggambarkan urgensinya dalam kehidupan manusia. Allah SWT mendahulukan perintah 'adl daripada ihsan dalam firman-Nya sebagai berikut:

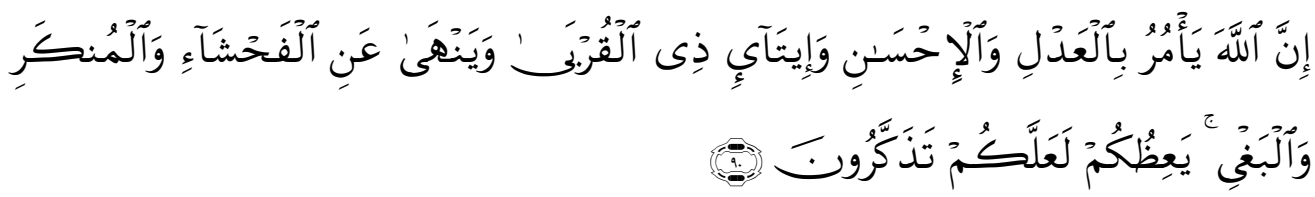

"Sesunggubnya Allab menyurub kamu berlaku adil dan berbuat kebajikan, memberi kepada kaum kerabat, dan Allah melarang dari perbuatan keji, kemungkaran dan permusuban.Dia memberi pengajaran kepadamu agar kamu dapat mengambil pelajaran”. (An-Nahl/16: 90)

Dalam kehidupan bermasyarakat, keadilan lebih utama daripada kedermawanan atau ihsan, memperlakukan pihak lain lebih baik dari perlakuannya, atau memperlakukan yang bersalah dengan perlakuan yang baik. ${ }^{15}$ Keadilan adalah salah satu dari empat keutamaan, yakni al-hikmah (kearifan), syaja'ah (keberanian), 'iffah (kesucian) dan 'adalah (keadilan). ${ }^{16}$

Dalam konteks hubungan antarmanusia, para pakar mengemukakan tiga makna keadilan dalam Alquran. Pertama, adil dalam arti sama. Seorang pemimpin dikatakan adil apabila ia memperlakukan sama atau tidak membedakan seseorang di antara rakyat dan pengikutnya dengan yang lain. Persamaan yang dimaksud adalah persamaan dalam hak. Allah swt berfirman,

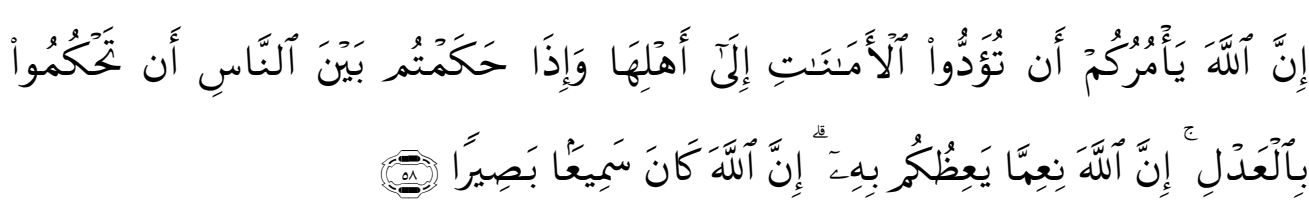

Sesunggubnya Allah menyuruh kamu menyampaikan amanat kepada yang berhake menerimanya, dan menyuruh kamu apabila memutuskan perkara di antara manusia, maka bendaklah engkau memutuskannya dengan adil.Sungguh Allah memberi pengajaran

12 Ahmad Warson Munawwir, Kamus Al-Munawnir (Surabaya: Pustaka Progresif, 1984), 971-972.

${ }^{13}$ Ibnu Manzhur, Lisanul 'Arab, juz 6 (Kairo: Darul Hadits, 2003), 123-125.

${ }^{14}$ Ibnu Manzhur, Lisanul 'Arab, juz 6,125-128, ar-Raghib al-Asfahani, Mu'jamu Mufadati Alfaşhil Quran (Beirut: Darul Fikr, t.t.h.), 336-337.

${ }^{15}$ M. Quraish Shihab, Wawasan Al-Quran, 124.

${ }^{16}$ Mujamma' allughah al-'Arabiyyah, al-Mu'jam al-Wasith (Kairo: Maktabah asy-Syuruq ad-Dauliyyah, 2004), 588. 
yangsebaik-baiknya kepadamu.Sesunggubnya Allah Maha Mendengar lagi Maha Melihat. (An-Nisa $/ 4: 58)$

Adil dalam ayat tersebut artinya sama dalam sikap dan perlakuan hakim pada saat proses mengambilan keputusan hukum. Hakim niscaya menempatkan pihak yang bersengketa di dalam posisi yang sama, misalnya mengenai tempat duduk, penyebutan nama, dengan atau tanpa embel-embel penghormatan, pandangan dan keceriaan wajah, kesungguhan mendengarkan, dan memikirkan ucapan mereka dalam proses pengambilan keputusan. ${ }^{17}$ Alquran mengajarkan tuntunan hidup tentang amanah. Allah SWT memerintahkan manusia agar memegang teguh amanah dan menyuruh manusia untuk berlaku adil. ${ }^{18}$

Alquran mengisahkan tentang dua orang yang datang berperkara kepada Nabi Daud as., untuk mencari keadilan. Orang pertama memiliki 99 ekor kambing, sedangkan yang kedua hanya memiliki satu ekor. Pemilik kambing yang banyak mendesak agar kambing yang seekor itu diberikan kepadanya supaya kambingnya genap seratus. Nabi Daud as memberikan kesempatan yang sama kepada kedua pihak untuk mengemukakan permasalahannya. Nabi Daud pun menyatakan bahwa pemilik 99 kambing itu telah berlaku aniaya atas permintaan itu, maka Nabi Daud tidak mengabulkannya.

Allah SW'T berfirman: "Adakah sampai kepadamu berita orang-orang yang berperkara ketika mereka memanjat pagar? Ketika mereka masuk menemui Daud lalu ia terkejut karena kedatangan mereka. Mereka berkata, "Janganlah kamu merasa takut; kami adalah dua orang yang berperkara yang salah seorang dari kami berbuat zalim kepada yang lain; maka berilah keputusan antara kami dengan adil dan janganlah kamu menyimpang dari kebenaran dan tunjukilah kami ke jalan yang lurus. Sesunggubnya saudaraku ini mempunyai sembilan puluh sembilan ekor kambing betina dan aku mempunyai seekor saja.Maka dia berkata, "Serabkanlah kambingmu itu kepadaku dan dia mengalabkan aku dalam perdebatan."Daud berkata, "Sesunggubnya dia telah berbuat ralim kepadamu dengan meminta kambingmu itu untuk ditambabkan kepada kambingnya.Dan sesunggubnya kebanyakan dari orang-orang yang berserikat itu sebagian mereka berbuat zalim kepada sebagian yang lain, kecuali orang-orang yang beriman dan mengerjakan amal yang saleh; dan amat sedikitlah mereka ini." Dan Daud mengetahui bahwa Kami mengujinya; maka ia meminta ampun kepada Tubannya lalu menyungkur sujud dan bertobat. Maka Kami ampuni kesalahannya itu. Sesunggubnya dia mempunyai kedudukan dekat pada Kami dan tempat kembali yang baik. Hai Daud, sesunggubnya Kami menjadikan kamu khalifah, penguasa, di muka bumi. Maka berilah keputusan perkara di antara manusia dengan adil dan janganlah kamu mengikuti hawa nafsu, karena ia akan menyesatkan kamu dari jalan Allah. Sesunggubnya orang-orang yang sesat darin jalan

${ }^{17}$ M. Quraish Shihab, Wawasan Al-Quran, 114.

${ }^{18}$ Lajnah Pentashihan Mushaf Kemenag RI, Tafsir Ringkas Al-Quran Al-Karim (Jakarta: Badan Litbang dan Diklat, 2016), 240. 
Allah akan mendapat azab yang berat, karena mereka melupakan hari perbitungan. (Shad/38: 21-26)

Kedua, adil dalam arti seimbang. Keseimbangan ditemukan pada suatu kelompok yang bekerja sama dengan pekerjaan dan tanggung jawab yang beragam. Maka masing-masing anggota kelompok itu memperoleh imbalan sesuai dan seimbang dengan beban dan tanggung jawabnya. Di sini keadilan identik dengan keproporsian. Keseimbangan tidak mengharuskan persamaan kadar bagi semua anggota. Bisa saja anggota yang satu menerima upah lebih banyak dari yang lain karena perbedaan kontribusinya dalam usaha bersama tersebut. ${ }^{19}$ Seorang pemimpin harus bersikap adil, amanah, dan mendahulukan kepentingan umum daripada kepentingan pribadi." 20

Allah SW'T berfirman dalam Alquran: "Babwasanya seorang manusia tiada memperoleb selain apa yang telah diusabakannya, dan babwasanya usaba itu kelak akan diperlihat kepadanya.Kemudian akan diberikan balasan kepadanya dengan balasan yang paling sempurna, dan bahwasanya kepada Tubamulah kesudaban segala sesuatu". (AnNajm/53:39-42)

Ketiga, adil dalam arti perbatian terbadap bak-bak individu dan memberikan bak-bak itu kepada setiap pemiliknya; menempatkan sesuatu pada tempatnya. Keadilan yang demikian melahirkan keadilan sosial. ${ }^{21}$

Makmur ialah hidup berkecukupan tak ada kekurangannya. ${ }^{22}$ Dalam konteks negara, kemakmuran ialah keadaan berkecukupan yang meliputi kehidupan seluruh rakyatnya. Masyarakat yang makmur ialah masyarakat yang sejahtera, senang, berada, berkecukupan, punya, mampu, dan kaya. ${ }^{23}$ Kemakmuran suatu negeri antara lain tergambar dalam kerajaan Ratu Saba` pada masa Nabi Sulaiman as.

Allah SWT berfirman: "Sesungguhnya bagi kaum Saba' ada tanda kekuasaan Tuban di tempat kediaman mereka, yaitu dua buah kebun di sebelah kanan dan di sebelah kiri. Kepada mereka dikatakan, "Makanlah olehmu dari rezeki yang dianugerabkan Tubanmu dan bersyukurlah kamu kepada-Nya.Negerimu adalab negeri yang baik dan Tubanmu adalah Tuban yang Maba Pengampun”. (Saba`/34: 15)

Negeri Saba berada di daerah Yaman di bawah pemerintahan Ratu Balqis. Selama beberapa abad negeri itu makmur dan bahagia, diairi dari bendungan Ma'rib yang melimpah, menghasilkan buah-buahan, rempah-rempah

\footnotetext{
${ }^{19}$ M. Quraish Shihab, Wawasan Al-Quran, 115.

${ }^{20}$ Lajnah Pentashihan Mushaf Kemenag RI, Tafsir Ringkas Al-Quran Al-Karim, 2:471.

${ }^{21}$ M. Quraish Shihab, Wawasan Al-Quran, 116.

22J. S. Badudu dan Sutan Mohammad Zain, Kamus Umum Bahasa Indonesia, 848.

${ }^{23}$ Eko Endarmoko, Tesaurus Bahasa Indonesia, 400.
} 
dan wewangian. ${ }^{24}$ Dalam ayat yang lain digambarkan bahwa negeri itu dikarunia dengan segala sesuatu.

Allah SWT berfirman: "Maka tidak lama kemudian datanglab bud-bud, lalu berkata, "Aku telah mengetabui sesuatu yang kamu belum mengetahuinya; dan kubawa kepadamu dari negeri Saba' suatu berita penting yang diyakini.Sesunggubnya aku menjumpai seorang wanita yang memerintab mereka, dan dia dianugerabi segala sesuatu serta mempunyai singgasana yang besar". (An-Naml/27:22-23)

Kemakmuran berlangsung sekian lama di negeri tersebut. Negeri itu enak dilihat, rakyatnya senang dan sejahtera, dan mereka dapat menikmati karunia Allah Yang Maha Penyayang. Tetapi di kemudian hari mereka berpaling, melakukan kekufuran dan kezaliman, menjadi sombong karena kemakmurannya atau karena ilmunya dan kepandaiannya. Maka Allah SWT menurunkan bencana banjir dari bendungan luar biasa yang telah dibangun nenek moyang mereka. ${ }^{25}$

\section{Perintah Berlaku Adil}

Keadilan adalah sebuah istilah yang menyeluruh, termasuk segala sifat yang bersih dan jujur. Tetapi Islam menuntut yang lebih hangat dan lebih manusiawi; melakukan pekerjaan yang baik meskipun tidak diharuskan secara ketat oleh keadilan. ${ }^{26}$ Keadilan mengandung arti memberi masing-masing haknya. ${ }^{27}$

Allah SWT menegaskan perintah kepada manusia untuk menegakkan keadilan dengan firman-Nya: "Sesunggubnya Allah menyurub kamu berlaku adil dan berbuat kebajikan, memberi kepada kaum kerabat, dan Allah melarang dari perbuatan keji, kemungkaran dan permusuban.Dia memberi pengajaran kepadamu agar kamu dapat mengambil pelajaran”. (An-Nahl/16: 90)

Allah SWT merangkai perintah berlaku adil dengan seruan untuk berbuat kebajikan dan memberi kepada kaum kerabat serta larangan melakukan perbuatan keji, munkar dan permusuhan. Ayat tersebut mengandung pesan bahwa dalam kehidupan bermasyarakat, keadilan lebih utama daripada kedermawanan atau ibsan yang titik tekannya pada kehidupan antar individu. ${ }^{28}$

Dalam konteks perintah kepada manusia untuk berlaku adil, dalam Alquran Allah SW'T menggunakan dua kosakata lain selain 'adl, yakni al-qisth dan al-mizan dalam berbagai bentuknya. Kata qisth dari akar kata qasathayaqsuthu/yaqsithu-qisth yang artinya berlaku adil, sedangkan kata mizan dari akar

\footnotetext{
${ }^{24}$ Abdullah Yusuf Ali, Quran Terjemahan, 1103.

${ }^{25}$ Abdullah Yusuf Ali, Quran Terjemahan, 1104.

26 Abdullah Yusuf Ali, Quran Terjemahan., 680.

${ }^{27}$ Kirdi Dipoyudo, Keadilan Sosial (Jakarta: CV Rahawali, 1985), 23.

${ }^{28}$ M. Quraish Shihab, Wawasan Al-Quran, 124.
} 
kata wazana-yazinu-mizan yang artinya timbangan, keadilan. ${ }^{29}$ Allah SWT berfirman:

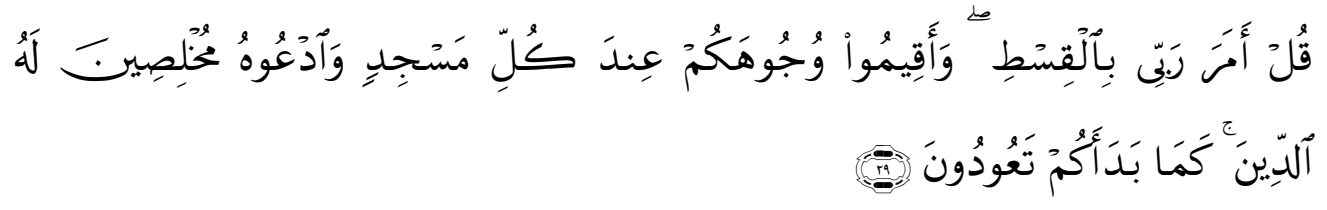

"Katakanlab, "Tubanku menyurub menjalankan keadilan," dan katakanlah, "Luruskanlah mukamu di setiap shalat dan sembablah Allah dengan mengikblaskan ketaatanmu kepada-Nya.Sebagaimana Dia telab menciptakan kamu pada permulaan, demikian pulalah kamu akan kembali kepada-Nya." (Al-A'raf/7:29)

Sesungguhnya Allah tidak pernah menyuruh melakukan perbuatan keji. Dia hanya menyuruh menegakkan keadilan dan kebenaran, meluruskan hati dan niat kepada Allah ketika menghadap-Nya menegakkan shalat dan ikhlas dalam beribadah kepadanya. ${ }^{30}$

\section{Dalam ayat yang lain Allah SW'T berfirman:}

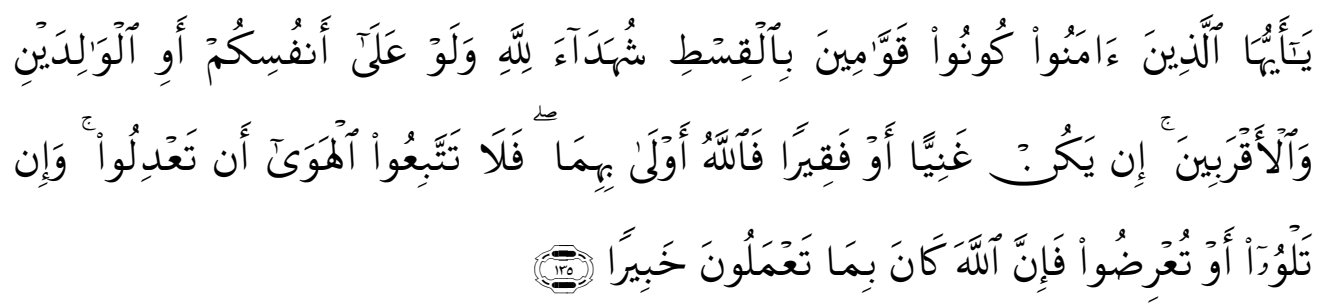

'Wabai orang-orang yang beriman, jadilah kamu orang yang benar-benar penegak. keadilan, menjadi saksi karena Allah biarpun terbadap dirimu sendiri atau ibu bapa dan kaum kerabatmu.Jika ia kaya ataupun miskin, maka Allah lebib tabu kemaslahatannya. Maka janganlah kamu mengikuti hawa nafsu karena ingin menyimpang dari kebenaran.Dan jika kamu memutarbalikekan kata-kata atau enggan menjadi saksi, maka sesunggubnya Allah Maba Mengetabui segala apa yang kamu kerjakan”. (An-Nisa`/4: 135).

Adil adalah sifat Allah. Untuk menegakkan keadilan orang harus menjadi saksi demi Allah, sekalipun itu akan mengganggu kepentingan diri sendiri atau orang-orang yang dekat dengannya. Peribahasa Latin menyatakan, "Keadilan harus berjalan sekalipun langit akan runtuh." ${ }^{\text {31 }}$

${ }^{29}$ Mujamma' allughah al-'Arabiyyah, al-Mu'jam al-Wasith, 734, 1029-1030, Ahmad Warson Munawwir, Kamus Al-Munawnir, 1201-1202, 1661-1662.

30 'Aidh Al-Qarni, Tafsir Muyassar, terjemah Ti Penerjemah Qisthi Press (Jakarta: Qisthi Press, 2008), 1:670.

${ }^{31}$ Abdullah Yusuf Ali, Quran Terjemahan, 223 
Keadilan Islam lebih tinggi daripada keadilan formal menurut hukum Romawi atau hukum mana pun yang dibuat manusia di muka bumi. Ia menembus sampai ke lubuk perasaan yang paling dalam, karena Muslim melakukannya sedang ia berada di hadapan Allah, Yang Maha Mengetahui segala benda, segala kerja dan gerak hati. Ada setengah orang yang mungkin cenderung mau mendukung pihak yang kaya, karena mengharapkan sesuatu dari pihaknya. Ada pula yang cenderung mau membantu pihak yang miskin, karena umumnya mereka orang-orang yang tak berdaya. Sikap memihak ke mana pun tidak benar. Mukmin niscaya bersikap adil, tanpa harus merasa takut atau terbawa oleh perasaaan. Baik yang miskin ataupun yang kaya, keduanya berada dalam perlindungan Allah, sepanjang kepentingan mereka sah, tetapi mereka tidak dapat mengharapkan keuntungan dengan mengorbankan pihak lain. ${ }^{32}$

Allah SWT berfirman: "Hai orang-orang yang beriman, hendaklah kamu jadi orang-orang yang selalu menegakekan kebenaran karena Allah, menjadi saksi dengan adil.Dan janganlah sekali-kali kebencianmu terhadap sesuatu kaum mendorong kamu untuk berlaku tidak adil.Berlaku adillah, karena adil itu lebih dekat kepada takwa.Dan bertakwalah kepada Allah, sesungguhnya Allah Maha Mengetabui apa yang kamu kerjakan”. (Al-Maidah/5: 8)

Keadilan harus ditegakkan dimanapun, kapanpun, dan terhadap siapapun. Bahkan, jika perlu dengan tindakan tegas, seperti diisyaratkan oleh ayat berikut yang menggandengkan timbangan, alat ukur yang adil, dengan besi yang digunakan sebagai senjata. ${ }^{33}$

Allah SWT berfirman: "Sesunggubnya Kami telah mengutus rasul-rasul Kami dengan membawa bukti-bukti yang nyata, dan telah Kami turunkan bersama mereka AlKitab dan neraca keadilan supaya manusia dapat melaksanakan keadilan. Dan Kami ciptakan besi yang padanya terdapat kekuatan yang hebat dan berbagai manfaat bagi manusia, supaya mereka mempergunakan besi itu, dan supaya Allab mengetahui siapa yang menolong agama-Nya dan rasul-rasul-Nya padahal Allab tidak dilihatnya. Sesunggubnya Allab Maba Kuat lagi Maba Perkasa”. (Al-Hadid/57: 25)

Dalam ayat yang lain Allah SWT berfirman:

'Dan Kami telah mengutus kepada penduduk Madyan saudara mereka, Syu'aib.Ia berkata, "Hai kaumku, sembablah Allah, sekali-kali tidak ada Tuban bagimu selain-Nya. Sesunggubnya telah datang kepadamu bukti yang nyata dari Tubanmu.Maka sempurnakanlah takaran dan timbangan, dan janganlah kamu kurangkan bagi manusia barang-barang takaran dan timbangannya, dan janganlah kamu membuat kerusakan di muka bumi sesudah Tuhan memperbaikinya.Yang demikian itu lebib baik bagimu jika kamu betul-betul orang-orang yang beriman" (Al-A'raf/7: 85)

${ }^{32}$ Abdullah Yusuf Ali, Quran Terjemahan, 223

${ }^{33}$ M. Quraish Shihab, Wawasan Al-Quran, 118. 
'Dan kepada penduduk. Madyan Kami utus saudara mereka, Syu'aib.Ia berkata, "Hai kaumku, sembablah Allah, sekali-kali tiada Tuban bagimu selain Dia. Dan janganlab kamu kurangi takaran dan timbangan, sesunggubnya Aku melihat kamu dalam keadaan yang baik, mampu, dan sesunggubnya aku khawatir terbadapmu akan azab bari yang membinasakan (kiamat).” (Hud/11: 84)

Tentang qisth Allah SWT berfirman: "Dan kalau ada dua golongan di antara mereka yang beriman itu berperang hendaklab kamu damaikan antara keduanya! Tetapi kalau yang satu melanggar perjanjian terhadap yang lain, hendaklah yang melanggar perjanjian itu kamu perangi sampai surut kembali pada perintah. Allah. Kalau dia telah surut, damaikanlah antara keduanya menurut keadilan, dan hendaklah kamu berlaku adil; sesunggubnya Allab mencintai orang-orang yang berlaku adil”. (Al-Hujurat/49: 9)

Allah SWT menggandengkan perintah untuk mendamaikan dua kelompok yang berselisih dengan keharusan berlaku adil, karena juru damai tidak boleh bertindak berat sebelah. Apabila juru damai bertindak berat sebelah, maka perdamaian tak akan terwujud, karena keadilan merupakan salah satu sendi kehidupan masyarakat sejahtera. Kebencian tidak dapat dijadikan alasan untuk mengorbankan keadilan, walaupun kebencian itu tertuju kepada kaum nonMuslim atau didorong oleh upaya untuk memperoleh ridha-Nya. ${ }^{34}$

Allah SWT berfirman: "Allah tidak melarang kamu untuk berbuat baik dan berlaku adil terhadap orang-orang yang tiada memerangimu karena agama dan tidak pula mengusir kamu dari negerimu. Sesunggubnya Allah menyukai orang-orang yang berlaku adil”. (Al-Mumtahanah/60: 8)

Berlaku adil adalah salah satu etika yang harus dijunjung tinggi oleh orang-orang beriman. Berlaku adil kepada siapa saja, kapan saja dan dimanapun ia berada, tanpa membedakan suku, agama, ras dan golongan.

\section{Langkah-langkah untuk Meraih Keadilan dan Kemakmuran menurut Alquran}

Manusia dalam masyarakat adalah satu kesatuan. Bahkan seluruh jagat raya merupakan satu kesatuan. Allah SWT berfirman: "Dan tiadalah binatangbinatang yang ada di bumi dan burung-burung yang terbang dengan kedua sayapnya, melainkan umat juga seperti kamu.Tiada Kami alpakan sesuatupun dalam Al-Kitab, kemudian kepada Tuhanlah mereka dibimpunkan”. (Al-An'am/6: 38)

Sepanjang mengenai kebutuhan jasmani, manusia dan makhluk lain, semua dicukupi kebutuhannya oleh Allah SWT. Oleh karena itu manusia harus tunduk kepada hukum alam seperti yang dilakukan oleh binatang. Tetapi kodrat manusia mempunyai cita-cita untuk mencapai sesuatu yang lebih tinggi, yaitu 
kepuasan rohani. Untuk tercapainya cita-cita rohani inilah Allah mengutus para Nabi dari zaman ke zaman. ${ }^{35}$

Salah satu prasyarat mewujudkan persatuan dan keharmonisan dalam kehidupan manusia ialah kedamaian. Allah SWT mengutus para nabi untuk memberi peringatan dan keputusan tentang perkara yang mereka perselisihkan. Allah SW'T berfirman: "Manusia adalah umat yang satu. Setelah timbul perselisiban, maka Allah mengutus para nabi, sebagai pemberi peringatan, dan Allah menurunkan bersama mereka Kitab yang benar, untuk memberi Keputusan di antara manusia tentang perkara yang mereka perselisibkan. Tidaklah berselisib tentang Kitab itu melainkan orang yang telah didatangkan kepada mereka kitab, yaitu setelah datang kepada mereka keterangan-keterangan yang nyata, karena dengki antara mereka sendiri.Maka Allah memberi petunjuk orang-orang yang beriman kepada kebenaran tentang bal yang mereka perselisibkann itu dengan kehendak-Nya.Dan Allab selalu memberi petunjuk. orang yang dikehendaki-Nya kepada jalan yang lurus". (Al-Baqarah/2: 213)

Manusia niscaya bekerja sama dan saling menopang demi kebahagiaan, kemakmuran dan kesejahteraan bersama. Apabila ada perselisihan di antara mereka, maka niscaya diselesaikan dengan cara yang seadil-adilnya. Untuk itu setiap anggota masyarakat harus rela berkorban demi kemaslahatan bersama dan berjuang demi mewujudkan cita-cita bersama. ${ }^{36}$ Allah SWT berfirman: "Mengapa kamu tidak mau berperang di jalan Allah dan membela orang-orang yang lemah, baik lakilaki, wanita-wanita maupun anak-anak yang semuanya berdoa, "Ya Tuban kami, keluarkanlah kami dari negeri ini yang zalim penduduknya dan berilab kami pelindung dari sisi Engkau, dan berilah kami penolong dari sisi Engkau!” (An-Nisa'/4: 75)

Manusia niscaya berjuang untuk menegakkan keadilan dan kesejahteraan umat manusia. Kezaliman, apapun bentuknya, dimanapun dan kapanpun, harus disingkirkan. Pengalaman demikian pernah dihadapi umat Islam generasi awal, ketika orang-orang kafir Mekah melakukan penyiksaan-penyiksaan terhadap orang-orang yang memeluk agama Islam seperti tergambar dalam ayat tersebut.

Berjuang menegakkan keadilan dan kebenaran merupakan misi kehidupan yang mulia. Allah SWT menggambarkan perjuangan pada jalan-Nya atas dasar iman sebagai perniagaan, transaksi; sesuatu yang diberikan atau diperbuat, ditukar dengan sesuatu yang ingin diterima. Allah memberikan tawarmenawar yang luar biasa. Apa yang diminta dari manusia sedikit sekali, sedangkan yang diberikan Allah SWT sangat banyak. ${ }^{37}$ Allah SWT berfirman: "Hai orang-orang yang beriman, sukakah kamu Aku tunjukkan suatu perniagaan yang dapat menyelamatkanmu dari azab yang pedib?Yaitu kamu beriman kepada Allah dan Rasul-Nya dan beriihad di jalan Allah dengan harta dan jiwamu.Itulah

${ }^{35}$ Maulana Muhammad Ali, Quran Suci, terjemah M. Bachrun (Jakarta: Darul Kutubil Islamiyah, 1979), 368 footnote 774 .

${ }^{36} \mathrm{M}$. Quraish Shihab, Wawasan Al-Quran, 122.

${ }^{37}$ Abdullah Yusuf Ali, Quran Terjemahan dan Tafsimya, 1440. 
yang lebih baik bagimu, jika kamu mengetahui.Niscaya Allah akan mengampuni dosadosamu dan memasuk.kanmu ke dalam surga yang mengalir di bawabnya sungai-sungai; dan memasukkan kamu ke tempat tinggal yang baik di dalam surga'Adn. Itulab keberuntungan yang besar". (Ash-Shaff/61: 10-12)

Tanda-tanda keberkahan dan kesejahteraan sosial kehidupan manusia tercermin dari surga yang dihuni oleh Adam dan istrinya Hawa, sebelum mereka turun ke bumi. Di dalam surga orang terhindar dari kesusahan dan kepayahan, kelaparan, kehausan, dan kekurangan sandang. Terpenuhinya kebutuhan sandang, pangan, dan papan merupakan unsur pertama dan utama kesejahteraan sosial. Allah SWT berfirman: "Maka Kami berkata, "Hai Adam, sesunggubnya Iblis adalah musubmu dan isterimu, maka sekali-kali janganlah sampai ia mengeluarkan kamu berdua dari surga, yang menyebabkan kamu menjadi celaka.Sesunggubnya kamu tidak akan kelaparan di dalamnya dan tidak akan telanjang. Sesungguhnya kamu tidak akan merasa dahaga dan tidak pula akan ditimpa panas matahari di dalamnya." (Thaha/20: 117119).

Allah SWT memenuhi kebutuhan Adam dan isrinya Hawa di dalam surga. Mereka tidak pernah merasa lapar dan telanjang di dalamnya. Mereka tidak pernah merasa haus dan tak akan merasakan teriknya matahari, seperti yang dirasakan oleh orang yang berusaha keras di luar surga. ${ }^{38}$

Prasyarat kesejahteraan sosial menurut Alquran ialah kehidupan yang penuh iman dan takwa kepada Allah SWT. Allah SWT niscaya melimpahkan segala berkah dari langit dan bumi bagi orang-orang yang beriman dan bertakwa kepada-Nya. Allah SWT berfirman: "Tikalau sekiranya penduduk negeri-negeri beriman dan bertakwa, pastilah Kami akan melimpabkan kepada mereka berkah dari langit dan bumi, tetapi mereka mendustakan ayat-ayat Kami itu, maka Kami siksa mereka disebabkan perbuatannya". (Al-A'raf/7: 96)

Allah SWT memerintahkan untuk beriman dan memohon ampun kepada-Nya, dan Dia menjanjikan ampunan, limpahan hujan dari langit, menambahkan harta kekayaan, anak-anak dan memberikan taman-taman dengan sungai-sungai yang melimpah airnya bagi orang yang bertakwa. Allah SWT berfirman: "Maka aku katakan kepada mereka, "Mohon ampunlah kepada Tubanmu, sesunggubnya Dia Maha Pengampun-, Dia akan mengirimkan bujan kepadamu dengan lebat.Dan memperbanyak barta dan anak-anak-mu, dan mengadakan untukmu kebunkebun dan mengadakan pula di dalamnya sungai-sungai”. (Nuh/71: 10-12)

Hujan merupakan suatu rahmat bagi manusia, lebih-lebih pada masa kekeringan dan kelaparan. Hujan menumbuhsuburkan tanaman dan menghasilkan panen yang melimpah. Kebun-kebun yang subur merupakan

38 Republik Arab Mesir, Al-Azhar dan Kementerian Wakaf Majelsi Tinggi Urusan Agama, Al-Muntakhab dalam Tafsir al-Quran al-Karim, terjemah Muchlis M. Hanafi dkk (Kairo: 2001), 647. 
impian abadi sebagai tanda kemakmuran, bukan saja dalam arti materi tetapi juga rohani. Mata air yang mengalir terus-menerus itu membawa kesejahteraan karena keberadaannya itu untuk selamanya. Mereka menjadi penduduk yang menetap, terhormat dan tenteram, dan dapat menikmati rahmat dan berkah Allah di muka bumi, sebagai tanda yang mendahului kenikmatan abadi di surga. $^{39}$

Kesejahteraan dan kemakmuran harus diusahakan bersama-sama.Yang kuat membantu yang lemah, yang kaya membantu yang miskin, yang pandai membantu yang kurang pengetahuan. Hal itu tertera dalam firman Allah SWT: "Tabukah kamu orang yang mendustakan agama?Maka itulab orang yang menghardik anak yatim,dan tidak mendorong memberi makan orang miskin.Maka celakalah orang yang salat,yaitu orang-orang yang lalai terbadap salatnya, yang berbuat ria, dan enggan memberikan bantuan”. (Al-Ma'un/107: 1-7)

Ayat tersebut di atas mengungkapkan tentang orang-orang yang termasuk dalam kategori mendustakan agama dan mengingkari hari pembalasan, yakni mereka yang menghardik anak yatim, menyakiti hatinya, dan berbuat zalim kepadanya dengan menahan haknya. Dia juga tidak mau mendorong orang lain untuk memberI makan orang miskin yang tidak mempunyai kecukupan untuk memenuhi keperluan hidupnya sehari-hari. ${ }^{40}$

\section{Penutup}

Orang beriman niscaya tergerak hatinya untuk meringankan beban kaum lemah dan miskin dan menyantuni mereka di bidang ekonomi, sosial, kesehatan, dan pendidikan. Adanya perbedaan sosial dalam masyarakat mengharuskan orang bekerjasama untuk meningkatkan taraf hidup dengan semangat gotongroyong dan timbang rasa. Kepedulian kepada kaum lemah mengurangi ketajaman perbedaan, mempererat solidaritas, dan memperkuat rasa sepenanggungan kepada sesama. Menolong orang dengan barang yang berguna meliputi zakat, harta benda, alat-alat rumah tangga, air, dan keperluan seharihari, seperti periuk, piring, dan cangkul.

Iman, agama, dasar-dasar hak dan batil dalam soal rohani sering berlawanan dengan keinginan-keinginan nafsu pribadi. Hanya manusia yang mengingkari iman dan tanggung jawab akhirat yang memperlakukan kaum yang lemah dengan sikap menghina, hidup serakah dan sombong. Amal kebaikan dan cinta kasih kepada sesama diwujudkan dengan memberi makan orang miskin, bersedekah, bersikap sopan, santun dan berbaik hati dalam kehidupan seharihari. Hal itu berada di luar jangkauan orang yang berhati batu, yang tidak mendorong, bahkan melarang atau memandang rendah orang yang beramal atau berbuat baik kepada orang lain. Masyarakat niscaya bekerja sama bahu-

\footnotetext{
${ }^{39}$ Abdullah Yusuf Ali, Quran Terjemahan dan Tafsirnya, 1503.

${ }^{40}$ Lajnah Pentashihan Mushaf Kemenag RI, Tafsir Ringkas Al-Quran Al-Karim, 2:1008.
} 
membahu untuk mewujudkan kehidupan yang adil dan makmur sepanjang masa, berdasarkan semangat kebersamaan dan kesetiakawanan sosial.

\section{Daftar Pustaka}

Abdullah Yusuf Ali, Quran Terjemahan dan Tafsirnya, terjemah Ali Audah. Jakarta: Pustaka Firdaus, 1994.

Ahmad al-Mursi Husain Jauhar, Maqashid Syariah, terjemah Khikmawati. Jakarta: Amzah, 2010.

Ahmad Warson Munawwir, Kamus Al-Munawwir. Surabaya: Pustaka Progresif, 1984.

'Aidh Al-Qarni, Tafsir Muyassar, terjemah Ti Penerjemah Qisthi Press. Jakarta: Qisthi Press, 2008.

Eko Endarmoko, Tesaurus Bahasa Indonesia. Jakarta: Gramedia, 2009.

J. S. Badudu dan Sutan Mohammad Zain, Kamus Umum Bahasa Indonesia.Jakarta: Pustaka Sinar Harapan, 1996.

Ibnu Manzhur, Lisanul 'Arab, juz 6. Kairo: Darul Hadits, 2003.

Kirdi Dipoyudo, Keadilan Sosial. Jakarta: CV Rahawali, 1985.

Lajnah Pentashihan Mushaf Kemenag RI, Tafsir Ringkas Alquran Al-Karim. Jakarta: Badan Litbang dan Diklat, 2016.

Majid Fakhry, Etika Islam, terjemah Zakiyuddin Baidhawy. Yogyakarta: Pustaka Pelajar, 1996.

Maria S.W. Sumardjono, "Memaknai Kembali Hak Menguasai Negara atas Sumberdaya Alam Pasca Putusan Mahkamah Konstitusi dan

Tindaklanjutnya", Kuliah Inaugurasi Akademi Ilmu Pengetahuan Indonesia di Universitas Gadjahmada Yogyakarta, 3 September 2013.

Maulana Muhammad Ali, Quran Suci, terjemah M. Bachrun. Jakarta: Darul Kutubil Islamiyah, 1979.

Muhammad Fuad Abdul Baqi, al-Mu'jamul Mufahras li Alfą̧bil Quran al-Karim. Kairo: Darul Hadits, 1991.

Mujamma' al-Lughah al-'Arabiyyah, al-Mu'jam al-W asith. Kairo: Maktabah asySyuruq ad-Dauliyyah, 2004.

M. Quraish Shihab, Wawasan Alquran. Bandung: Mizan, 2007. , Tafsir Al-Mishbah, Jakarta: Lentera Hati, 2003.

ar-Raghib al-Asfahani, Mu’jamu Mufadati Alfą̧il Quran. Beirut: Darul Fikr, t.t.h. 
184 | AL QUDS : Jurnal Studi Al Quran dan Hadis vol. 1, no 2, 2017

Republik Arab Mesir, Al-Azhar dan Kementerian Wakaf Majelsi Tinggi Urusan Agama, Al-Muntakhab dalam Tafsir Alquran al-Karim, terjemah Muchlis M. Hanafi dkk. Kairo: 2001.

Zaini Dahlan, Tafsri Al-FAtihah dan Juz 30. Yogyakarta: UII Press, 2010. 